Louisiana State University

LSU Digital Commons

$3-1-2020$

\title{
Heat shock protein 70 levels and post-harvest survival of eastern oysters following sublethal heat shock in the laboratory or conditioning in the field
}

Sandra M. Casas

LSU Agricultural Center

Jerome F. La Peyre

LSU Agricultural Center

Follow this and additional works at: https://digitalcommons.Isu.edu/animalsciences_pubs

\section{Recommended Citation}

Casas, S., \& La Peyre, J. (2020). Heat shock protein 70 levels and post-harvest survival of eastern oysters following sublethal heat shock in the laboratory or conditioning in the field. Cell Stress and Chaperones, 25 (2), 369-378. https://doi.org/10.1007/s12192-019-01056-1 


\title{
Heat shock protein 70 levels and post-harvest survival of eastern oysters following sublethal heat shock in the laboratory or conditioning in the field
}

\author{
Sandra M. Casas $^{1}$ (D) Jerome F. La Peyre ${ }^{1}$ \\ Received: 21 August 2019 / Revised: 20 November 2019 / Accepted: 25 November 2019 / Published online: 8 January 2020 \\ (C) Cell Stress Society International 2020
}

\begin{abstract}
A major problem of storing and shipping eastern oysters (Crassostrea virginica) from the Northern Gulf of Mexico in summer and early fall is their elevated mortality. A study was therefore conducted to determine whether heat shocking the oysters or conditioning them to aerial exposure prior to harvest could reduce their mortality during cold storage. Increasing the levels of stress proteins in bivalves has been shown to reduce their mortality when exposed to additional stressors. In this study, the levels of heat shock protein 70 (HSP70) proteins and cumulative mortality during cold storage, out of water, of market-sized oysters were measured, in summer, following (1) sublethal heat shocks ( $\left.41^{\circ} \mathrm{C}, 1 \mathrm{~h}\right)$ in the laboratory or (2) 3 weeks to 6 weeks of daily exposures to air $(0 \mathrm{~h}, \sim 10 \mathrm{~h}$, or $\sim 18 \mathrm{~h})$ in the field. In total, four heat shock and two aerial exposure studies were done. Consistently, heat shocks or 6 weeks of daily aerial exposures increased HSP70 levels in oysters but did not reduce their mortality during cold storage. Three weeks of daily aerial exposure did not increase HSP70 levels and only marginally reduced mortality; a significant reduction in cumulative mortality occurred in one of the aerial exposure studies after 7 days of cold storage $(0 \mathrm{~h}$ [ $26 \%]$, $\sim 18 \mathrm{~h}$ [8\%]). In conclusion, upregulation of HSP70 proteins or aerial exposure during grow-out was not an effective tool in reducing the mortality of oysters harvested in summer and held in cold storage.
\end{abstract}

Keywords Aquaculture $\cdot$ Crassostrea virginica $\cdot$ Intertidal emersion · Aerial survival

\section{Introduction}

A major problem for the oyster industry of the Northern Gulf of Mexico (NGoM) is the elevated mortality of oysters out of the water in cold storage following their harvest in summer and early fall. During storage and shipping, those oysters start to gape and die earlier and at higher rates than in the rest of the year. Solutions for extending the refrigerated shelf life generally involve using post-harvest processing technologies such as high hydrostatic pressure, heat-cool pasteurization, individually quick freezing, or irradiation (Baker 2016; Ronholm et al. 2016). These processes reduce the oyster bacterial numbers and consequently increase their shelf life by preventing microbial spoilage (Hesselman et al. 1999; Andrews et al.

Sandra M. Casas

SCasasListe@agcenter.1su.edu

1 School of Animal Sciences, Louisiana State University Agricultural Center, Baton Rouge, LA 70803, USA
2000); however, they have the disadvantages of killing the oysters, which may reduce their palatability with time, and the industry has to invest in expensive equipment that may be used only in summer (Kingsley 2014; Baker 2016). The idea that exposing oysters to air during their grow-out could extend their post-harvest survival was suggested in one study in which European (Ostrea edulis) and eastern (Crassostrea virginica) oysters were cultured in the intertidal zone (Gillmor 1978). Exposing oysters to air during their grow-out is also widely used by the Australian oyster industry because, in addition to controlling biofouling and mudworm infestation, it hardens shell edges and adductor muscles which are thought to improve post-harvest survival during storage and shipping (Crawford 2016). In a recent study, it was found that adductor muscles had firmer texture in refrigerated eastern oysters that had been exposed to air daily, prior to harvest, compared to those continuously immersed (Zhang et al. 2017). The harder shell edges and firmer textures of the adductor muscles might indicate a better ability of the oysters to stay closed longer out of the water, preventing loss of shell cavity liquid and desiccation. Oysters growing in the intertidal zone experience 
prolonged periods of valve closure during their emersion and may be better adapted to the stress of cold storage out of water than oysters that have been continuously immersed prior to harvest.

Intertidal and sessile bivalves are exposed to a number of environmental stressors during emersion, especially in summer, from large changes in body temperature to high temperature, anoxia, and desiccation. Organisms from bacteria to humans protect their cells from the damages caused by environmental stressors by producing stress or heat shock proteins (HSPs) (Lindquist and Craig 1988; Feder and Hofmann 1999). In unstressed cells, constitutive HSPs are involved in folding, transportation, regulation, and degradation of proteins. Under environmental stressors, cells also produce inducible HSPs, increasing their total HSP levels, to protect proteins from denaturation and to refold or eliminate denatured proteins (Sanders 1993; Feder and Hofmann 1999). Among HSPs, the $70 \mathrm{kDa}$ family (HSP70) is the most temperature sensitive and conserved, accounting for much of the translational activity in cells responding to environmental stressors (Kregel 2002; Fabbri et al. 2008). In bivalves, numerous studies have demonstrated that a sublethal heat shock results in a temporary increase of tolerance to an otherwise lethal temperature, and this induced thermotolerance is associated with elevated levels of HSP70 proteins (Clegg et al. 1998; Encomio and Chu 2007; Brun et al. 2009). Other stressors such as hydrocarbons, anoxia, or low salinity can also increase HSP70 protein levels (Cruz-Rodriguez and Chu 2002; Monari et al. 2011), and the upregulation of HSP70 proteins enhances the tolerance to a wide range of additional stressors including hypoxia, acidosis, and pollutants (Lindquist and Craig 1988; Sanders 1993). Increasing the levels of HSP70 proteins has also been suggested as a potential method to enhance the shelf life of harvested bay scallops, Argopecten irradians irradians (Brun et al. 2009).

Eastern oysters are well adapted to survive in the intertidal zone, as historically, their populations formed large and structurally complex intertidal reefs (Hargis and Haven 1999). Moreover, air exposure has also been reported to increase oyster survival and growth and possibly reduce the impacts of pathogens (Gillmor 1982; Littlewood et al. 1992; La Peyre et al. 2018). An inducible (hsp69) and one (hsc72) or two constitutive (hsc72, hsc77) isoforms, depending on the antibody used, have been reported to make up eastern oyster HSP70 proteins (Encomio and Chu 2007; Ueda et al. 2009; Jackson et al. 2011). The sum of the isoforms is considered the most reliable metric of thermotolerance, and the accumulation of these HSP70 proteins correlates with an overall increase of stress tolerance (Fabbri et al. 2008; Jackson et al. 2011). Our objectives were therefore to determine whether increasing the levels of HSP70 proteins through their upregulation or induction by exposing eastern oysters to (1) a sublethal heat shock in the laboratory $\left(41^{\circ} \mathrm{C}, 1 \mathrm{~h}\right)$ or (2) temporary (3 weeks or
6 weeks) daily aerial exposure in the field, in summer, could reduce oysters' mortality during their refrigeration in cold air.

\section{Materials and methods}

\section{Oysters}

Market-size oysters ( $\geq 75 \mathrm{~mm}$ shell height) were obtained from the Louisiana Sea Grant Oyster Hatchery where they were grown in bags $(1.2 \mathrm{~cm}$ mesh, $76 \mathrm{~cm} \times 20.5 \mathrm{~cm} \times$ $21.7 \mathrm{~cm}$ ) held subtidally on an adjustable longline system (ALS) built in shallow waters off the northwest side of Grand Isle, Barataria Bay, Louisiana, an area with diurnal tides averaging $0.3 \mathrm{~m}$ (La Peyre et al. 2018). The height at which the oyster bags were suspended could be adjusted by moving the longline along riser posts placed about $3 \mathrm{~m}$ apart (http://www.bstoysters.com).

\section{Study 1: HSP70 protein levels and cumulative mortality during cold storage of oysters exposed to heat shock in the laboratory}

About 120 oysters were collected from ALS bags; transported to Louisiana State University Agricultural Center (LSU), Baton Rouge; and placed in a 700-L tank with recirculating artificial seawater (Crystal Sea, Marinemix; Marine Enterprises International, Baltimore, MD, USA). The salinity $(\sim 20 \mathrm{ppt}$ to $25 \mathrm{ppt})$ and temperature $\left(\sim 27^{\circ} \mathrm{C}\right.$ to $\left.30^{\circ} \mathrm{C}\right)$ of the tank were adjusted to the conditions in Grand Isle at the time of collections. Oysters were fed daily at $\sim 5 \%$ of their meat dry weight with Shellfish Diet $1800^{\circledR}$ (Reed Mariculture Inc., Campbell, CA, USA) and acclimated for 2 weeks prior to heat shocking to reduce the effects of handling and changes of environmental conditions from field to laboratory. After acclimation, 60 oysters were heat shocked by placing them for $1 \mathrm{~h}$ in 50-L aquaria filled with aerated artificial seawater heated to $41{ }^{\circ} \mathrm{C}$. At the same time, another group (control) of 60 oysters was placed for $1 \mathrm{~h}$ in aquaria filled with aerated artificial seawater maintained at room temperature. All oysters were then returned to the 700-L tank and fed daily. After a week, eight oysters from each group were shucked and their gills were stored at $-80{ }^{\circ} \mathrm{C}$ until used to measure HSP70 protein levels with an enzyme-linked immunosorbent assay (ELISA) following La Peyre et al. (2014). The remaining oysters, about 50 per group, were placed in trays and stored in a walk-in cooler at $\sim 4{ }^{\circ} \mathrm{C}$ for 21 days. The number of dead oysters was recorded every other day, dead oysters were removed, and cumulative mortalities were calculated on days 7,15 , and 21 . While Gulf oysters can stay alive longer than 21 days at $\sim 4{ }^{\circ} \mathrm{C}$, a maximum shelf life of 21 days is recommended because of changes in flavor and texture quality during storage (Wang 2015; Zhang et al. 2017). The study was repeated four 
times in October 2007, September 2008, June 2009, and August 2009.

\section{Study 2: HSP70 protein levels and cumulative mortality during cold storage of oysters after being continuously immersed or exposed to air daily for either a moderate $(\sim 10 \mathrm{~h})$ or long $(\sim 18 \mathrm{~h})$ time interval over a 3-week or 6-week period in the field}

The ALS was used to maintain oysters under the following three conditions: (1) exposure to air daily for approximately $8-12 \mathrm{~h}$ at low tide ( $\sim 10 \mathrm{~h}$ or $\sim 42 \%)$, (2) exposure to air daily for approximately $16-20 \mathrm{~h}$ at low tide $(\sim 18 \mathrm{~h}$ or $\sim 75 \%)$, and (3) continuous immersion (subtidal). Under each condition, four bags, with 25 oysters per bag, were placed on the ALS for either 3 weeks or 6 weeks. Bags held for 3 weeks were placed on the ALS 3 weeks after placing the bags held for 6 weeks so that all oysters were sampled and compared at the same time. At sampling, all bags were collected and the numbers of dead and live oysters were counted. Eight oysters per treatment were shucked, and their gills were stored in dry ice, transported to LSU, and stored at $-80{ }^{\circ} \mathrm{C}$ until HSP70 protein measurement. About 50 oysters per treatment were transported to LSU and stored in a walk-in cooler for 21 days, and their mortalities were recorded as described above. The study was repeated twice, in June and August 2009.

Temperatures in the subtidal bags and the bags exposed daily to air for $\sim 10 \mathrm{~h}$ or $\sim 18 \mathrm{~h}$ were monitored every 30 min using ACR Smart Button data logger temperature recorders (ACR Systems Inc., Surrey, B.C., Canada). ACR buttons were protected from seawater with parafilm sealing film and were placed in the bags, inside a 3-in.-long, 1-in.wide polyvinyl chloride pipe with caps at both ends that were drilled to let seawater in. Additionally, for the studied period and the same 30-min intervals, water temperatures were obtained from the USGS Barataria Pass monitoring station at Grand Isle (USGS recorder 073802516) and air temperatures were obtained from the NOAA station at Grand Isle (GISL-1).

\section{Statistical analysis}

All statistical analyses were done using SigmaStat (version 3.5; Systat Software Inc., Chicago, IL, USA). Gill HSP70 protein levels and temperatures were analyzed for normality using the Kolmogorov-Smirnov test and for equal variance using the Levene median test. Gill HSP70 protein levels and temperatures were compared with a one-factor ANOVA followed by Tukey's multiple comparison tests when significant differences were found $(P<0.05)$. The cumulative mortalities of oysters held in cold storage for 7 days, 15 days, or 21 days were analyzed with a series of chi-square tests. The mortalities of oysters at the end of their field deployment were also analyzed with chi-square tests. All data are reported as means \pm standard deviation.

\section{Results}

\section{Study 1: HSP70 protein levels and cumulative mortality during cold storage of oysters exposed to heat shock in the laboratory}

HSP70 protein levels in control oysters ranged between $400 \pm$ $105 \mathrm{ng} \mathrm{mg}^{-1}$ protein in August 2009 and $672 \pm 154 \mathrm{ng} \mathrm{mg}^{-1}$ in June 2009. Heat shocking the oysters for $1 \mathrm{~h}$ at $41^{\circ} \mathrm{C}$ significantly increased their HSP70 protein levels in the studies done in October $2007(P=0.002)$, September $2008(P=$ $0.003)$, and August $2009(P<0.001)$, but not in June 2009 $(P=0.411)$ (Fig. 1). HSP70 protein levels of heat-shocked oysters were between 1.4 and 2.4 times greater than those of control oysters.

No difference in cumulative mortalities could be shown in the October 2007, September 2008, June 2009, and August 2009 studies between control and heat-shocked oysters after they were placed in the walk-in cooler for 7 days, 15 days, or 21 days (Fig. 1, Table 1).

\section{Study 2: HSP70 protein levels and cumulative mortality during cold storage of oysters after being continuously immersed or exposed to air daily for either a moderate $(\sim 10 \mathrm{~h})$ or long $(\sim 18 \mathrm{~h})$ interval over a 3-week or 6-week period in the field}

At the end of the June 2009 field deployment, significant differences in oyster mortalities were found among treatments. The mortality of oysters exposed to air for $\sim 18 \mathrm{~h}$ daily over 6 weeks $(21 \%)$ was significantly greater than the mortalities of oysters exposed to air for $\sim 10$ h daily over 6 weeks $(7 \%)$ and of all oysters held over 3 weeks $(0 \mathrm{~h}[3 \%], \sim 10 \mathrm{~h} \mathrm{[3 \% ],} \mathrm{18} \mathrm{h}$ [3\%]). The mortality of oysters immersed for 6 weeks was $9 \%$, and differences with the mortalities of the other five treatments could not be shown.

Significant differences in HSP70 protein levels were only found among oysters held for 6 weeks in the field $(P=0.031$, Fig. 2) with oysters exposed to air for $\sim 10$ h daily having a greater mean HSP70 protein concentration than oyster immersed continuously.

Significant differences in the cumulative mortalities of oysters in cold storage were only found among oysters held over 3 weeks in the field prior to harvest (Fig. 2, Table 2). After 7 days in the walk-in cooler, oysters that had been exposed to air for $\sim 18 \mathrm{~h}$ daily had a lower cumulative mortality than oysters continuously immersed or exposed to air for $\sim 10 \mathrm{~h}$ daily. After 15 days, oysters that had been exposed to air for $18 \mathrm{~h}$ daily continued to have a lower cumulative mortality than 
Fig. 1 Study 1 HSP70 levels in control and heat-shocked oysters measured 7 days after exposure to $41{ }^{\circ} \mathrm{C}$ for $1 \mathrm{~h}$. Different letters represent statistical differences $(P<0.05)$. Seven days after the heat shock, oysters were stored in a walk-in cooler at $4{ }^{\circ} \mathrm{C}$, and their cumulative mortality (\%) followed every other day for 21 days
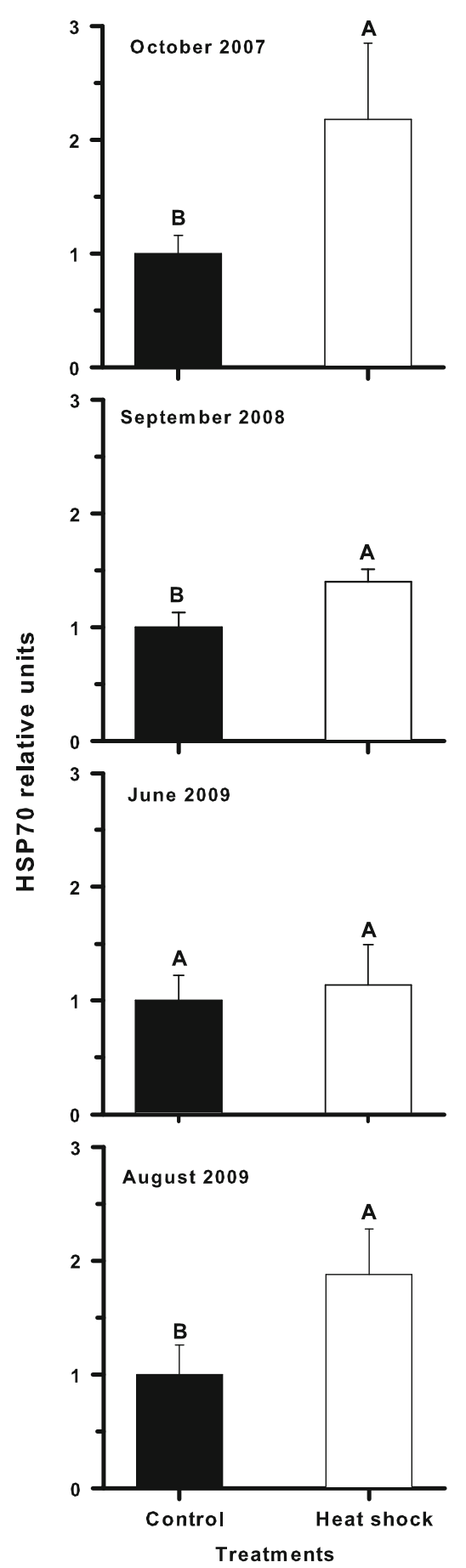
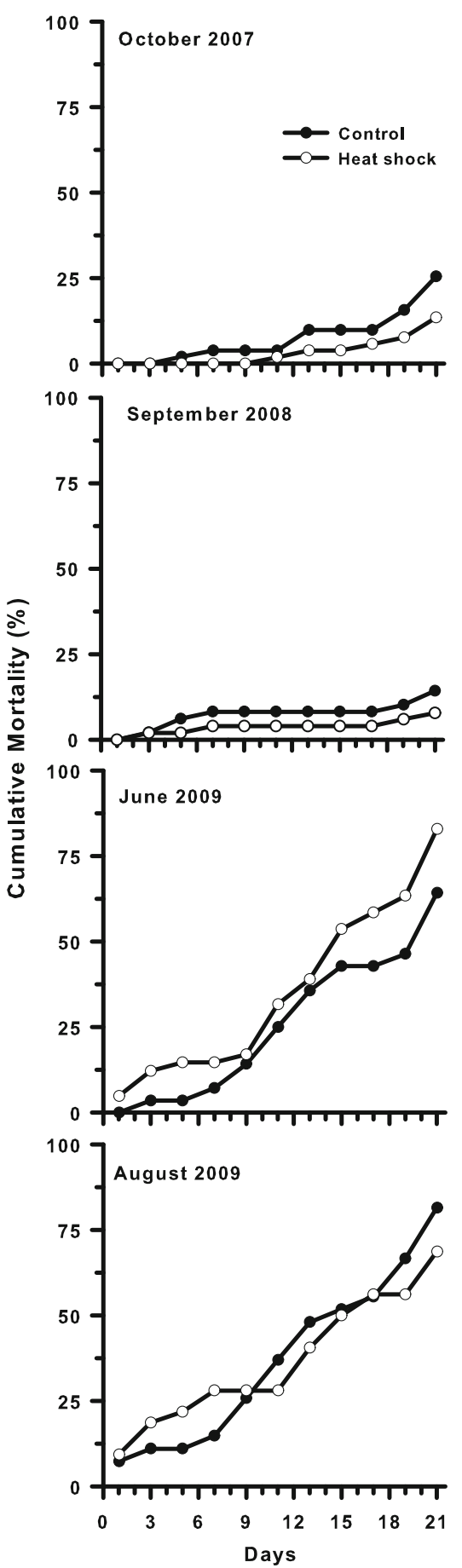

oysters that had been exposed to air for $\sim 10 \mathrm{~h}$ daily. After 21 days in the walk-in cooler, differences among cumulative mortalities were not found (Table 2).

Following similar differences between the air $(27.8 \pm$ $0.9^{\circ} \mathrm{C}$ ) and water $\left(29.4 \pm 0.7{ }^{\circ} \mathrm{C}\right)$ temperatures (Fig. 3), the mean temperature inside ALS bags exposed to air for $\sim 18 \mathrm{~h}$ daily $\left(27.7 \pm 1.9^{\circ} \mathrm{C}\right)$ was significantly lower $(P=0.003)$ than inside subtidal bags $\left(28.8 \pm 1.0^{\circ} \mathrm{C}\right)$.
At the end of the August 2009 field deployment, no differences in field mortality were found among treatments (3 weeks, 0 h [5\%], $10 \mathrm{~h} \mathrm{[2 \% ],} \sim 18 \mathrm{~h} \mathrm{[6 \% ];} 6$ weeks, $0 \mathrm{~h}$ [5\%], $\sim 10$ h [8\%], 18 h [9\%]; $P=0.463$ ).

Similar to the June 2009 field deployment results, significant differences in HSP70 protein levels were only found among oysters held for 6 weeks in the field $(P<0.001$, Fig. 2). Mean HSP70 protein concentration 
Table 1 Cumulative mortalities (\%) of oysters in study 1 after 7 days, 15 days, and 21 days of storage out of water at $4{ }^{\circ} \mathrm{C}$. Also shown are the results of chisquare analyses to test the effects of heat shock on cumulative mortalities

\begin{tabular}{|c|c|c|c|c|c|c|c|c|}
\hline \multirow[t]{2}{*}{ Trials } & \multirow[t]{2}{*}{ Treatment } & \multirow[t]{2}{*}{$N$} & \multicolumn{3}{|c|}{ Cumulative mortality (\%) } & \multicolumn{3}{|c|}{$\chi^{2} P$ values } \\
\hline & & & 7 days & 15 days & 21 days & 7 days & 15 days & 21 days \\
\hline October 2007 & $\begin{array}{l}\text { Control } \\
\text { Heat shock }\end{array}$ & $\begin{array}{l}51 \\
52\end{array}$ & $\begin{array}{l}4 \\
0\end{array}$ & $\begin{array}{l}10 \\
4\end{array}$ & $\begin{array}{l}26 \\
14\end{array}$ & 0.467 & 0.418 & 0.196 \\
\hline September 2008 & $\begin{array}{l}\text { Control } \\
\text { Heat shock }\end{array}$ & $\begin{array}{l}49 \\
51\end{array}$ & $\begin{array}{l}8 \\
4\end{array}$ & $\begin{array}{l}8 \\
4\end{array}$ & $\begin{array}{l}14 \\
8\end{array}$ & 0.637 & 0.637 & 0.478 \\
\hline June 2009 & $\begin{array}{l}\text { Control } \\
\text { Heat shock }\end{array}$ & $\begin{array}{l}28 \\
41\end{array}$ & $\begin{array}{l}7 \\
15\end{array}$ & $\begin{array}{l}43 \\
54\end{array}$ & $\begin{array}{l}64 \\
83\end{array}$ & 0.568 & 0.525 & 0.139 \\
\hline August 2009 & $\begin{array}{l}\text { Control } \\
\text { Heat shock }\end{array}$ & $\begin{array}{l}27 \\
32\end{array}$ & $\begin{array}{l}15 \\
28\end{array}$ & $\begin{array}{l}52 \\
50\end{array}$ & $\begin{array}{l}82 \\
69\end{array}$ & 0.361 & 0.905 & 0.413 \\
\hline
\end{tabular}

was greatest in oysters exposed to air for $\sim 18 \mathrm{~h}$ daily and lowest in oysters continuously immersed.

Significant differences in the cumulative mortalities of oysters in cold storage were only found among oysters that had been held 3 weeks in the field prior to being placed in the walk-in cooler (Fig. 2, Table 2). After 15 days in the walk-in cooler, oysters that had been exposed to air for $\sim 18 \mathrm{~h}$ daily had lower cumulative mortality than oysters exposed to air for $\sim 10 \mathrm{~h}$ daily. Differences among cumulative mortalities after 7 days or 21 days were not found (Table 2).

In the August 2009 experiment, mean air temperature $\left(28.9 \pm 1.1^{\circ} \mathrm{C}\right)$ was also significantly lower $(P<0.001)$ than mean water temperature $\left(30.8 \pm 0.7^{\circ} \mathrm{C}\right)$ (Fig. 3). The mean temperature inside ALS bags exposed to air for $\sim 18 \mathrm{~h}$ daily $\left(29.5 \pm 1.2^{\circ} \mathrm{C}\right)$ was also lower than that inside bags exposed to air for $\sim 10 \mathrm{~h}$ daily $\left(30.4 \pm 1.0^{\circ} \mathrm{C}\right)$ and bags continuously immersed $\left(30.2 \pm 0.9^{\circ} \mathrm{C}\right)(P<0.001)$.

\section{Discussion}

Increasing the HSP70 protein levels of NGoM eastern oysters by either heat shocking the oysters for $1 \mathrm{~h}$ at $41{ }^{\circ} \mathrm{C}$ in the laboratory or exposing them to air for $\sim 10 \mathrm{~h}$ or $\sim 18 \mathrm{~h}$ daily for 6 weeks in summer did not reduce their cumulative mortality during cold storage. Exposing oysters to air daily for $18 \mathrm{~h}$ over a period of 3 weeks instead of 6 weeks marginally increased their survival in cold storage and did not increase their HSP70 protein levels. Surprisingly, temperatures within ALS bags holding oysters out of the water for $\sim 18 \mathrm{~h}$, daily, were slightly but significantly lower than those in continuously immersed ALS bags because of cooler air than water temperatures. It is likely that shading and sedimentation were effective in keeping the temperature within the bags from increasing when the bags were out of water, during the day. Overall, neither heat shocking in the laboratory nor daily aerial field exposure prior to harvesting could substantially increase the survival of oysters in cold storage, out of water, following their harvest in summer and early fall.

Heat shocking oysters significantly increased their HSP70 protein levels in late summer and fall but not in early summer (June). During these periods, daily water temperatures are constantly elevated in NGoM. For example, the mean water temperature $( \pm \mathrm{SD})$ off Grand Isle between early June and late September was $30.3 \pm 1.2{ }^{\circ} \mathrm{C}$ in 2006 and $30.2 \pm 1.3{ }^{\circ} \mathrm{C}$ in 2007 (La Peyre et al. 2018). Other factors such as the stress of spawning may be partly responsible for differences in HSP70 responses between studies. Oysters in subtropical NGoM can spawn as early as May when water temperature exceeds $25^{\circ} \mathrm{C}$ (Supan and Wilson 2001), and post-spawning is a significant period of stress for oysters (Cho and Jeong 2005; Li et al. 2007; Huvet et al. 2010). The large initial reproductive effort of NGoM oysters is followed by gametogenic cycling and smaller spawning events that can last until October. Moreover, the additional production of HSP carries an elevated energetic cost that might not be met in June in NGoM oysters when the energy reserves have been depleted following the high energetic investment in gonad development and spawning (Hawkins 1985; Feder and Hofmann 1999; Li et al. 2009). Our results are in agreement with $\mathrm{Li}$ et al. (2007) who found no increase of hsc 72 or hsp69 proteins in post-spawning Pacific oysters (Crassostrea gigas) following a heat shock in contrast to pre-spawning oysters which exhibited about a twofold increase in hsc72 and a threefold increase in hsp69. Concomitant with the influence of reproductive condition, thermal history is well known to affect the temperature at which HSPs are induced and the magnitude of their expression (Roberts et al. 1997; Encomio and Chu 2007; Li et al. 2007). For example, the levels of HSP70 proteins of California mussels (Mytilus californianus) collected at different times of the year differed, and the magnitude by which their levels increased upon heat shocking in the laboratory ranged from a factor of 4 in mussels collected in February to no increase in mussels collected in August (Roberts et al. 1997). Overall, there appears to be no relationship between 
Fig. 2 Study 2 HSP70 levels in field oysters continuously immersed $(0 \mathrm{~h})$ or exposed to air for $\sim 10 \mathrm{~h}$ or $\sim 18 \mathrm{~h}$ daily over a 3 week or 6-week period. Different letters represent statistical differences $(P<0.05)$. Cumulative mortality $(\%)$ following harvesting and refrigeration for 21 days

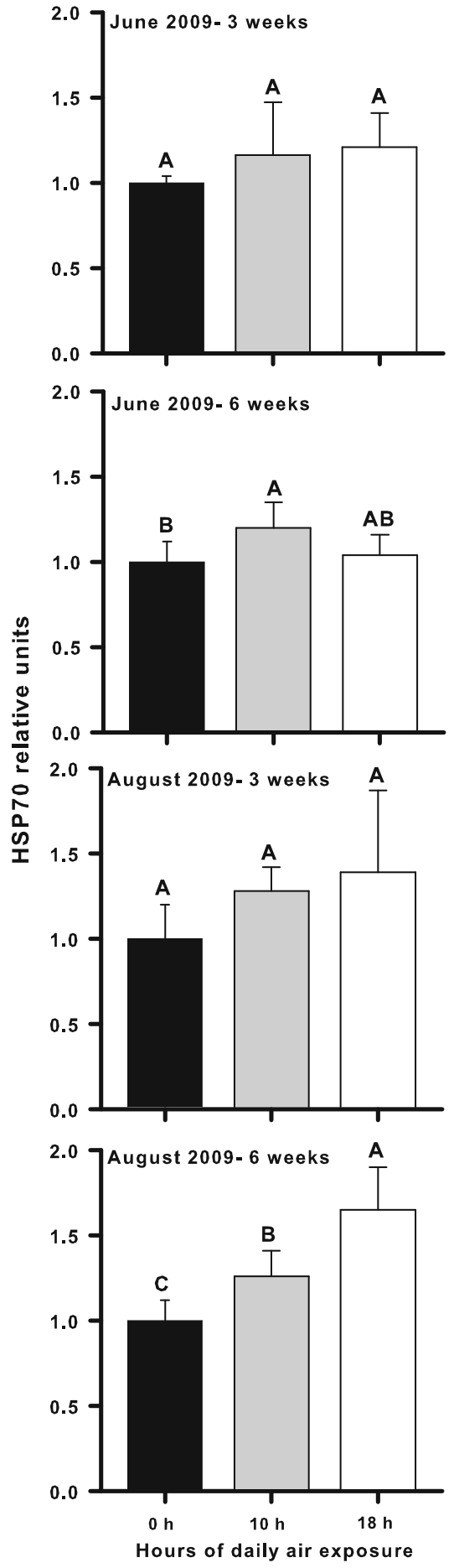

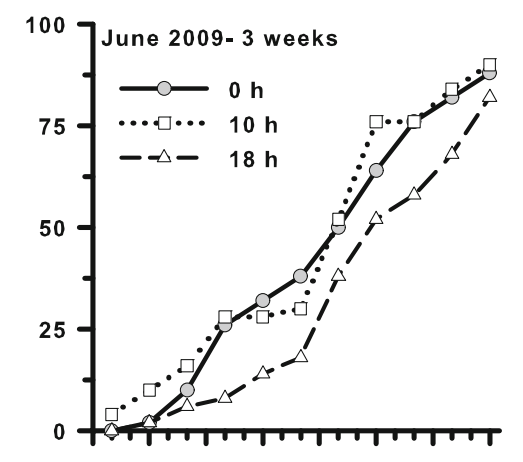
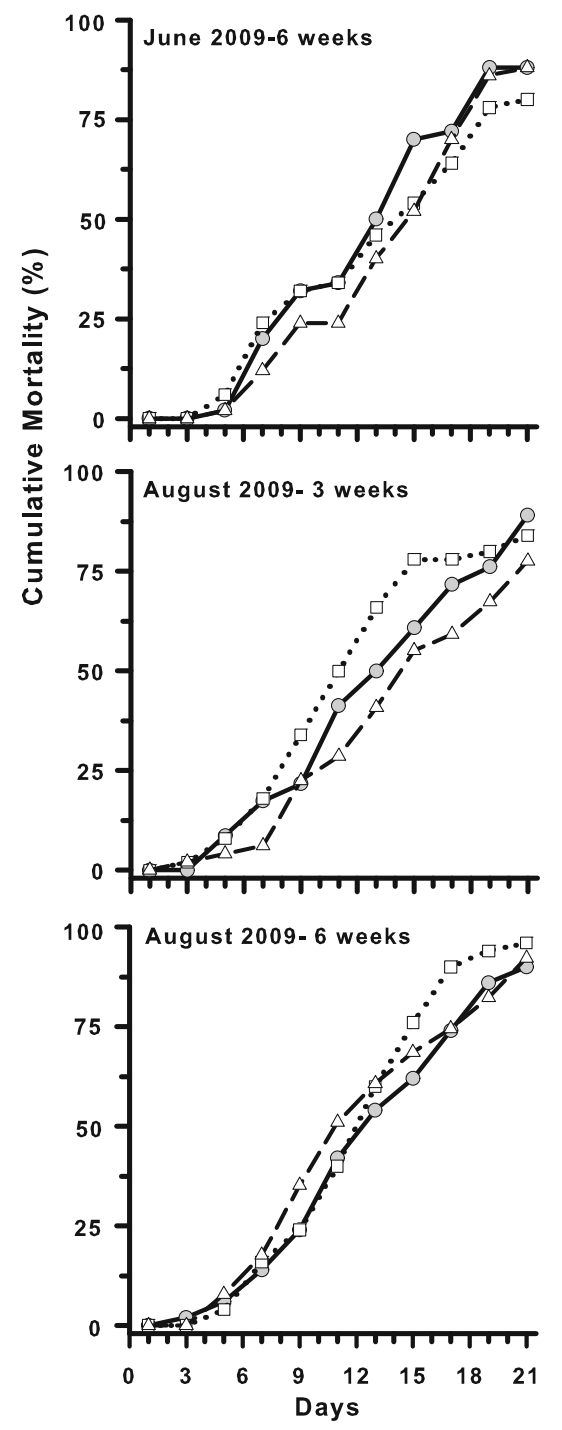

the levels of HSP70 proteins, as measured in our study, and the survival of oysters in cold storage. This is in contrast to reported increase in the tolerance of oysters and other bivalves to heat stress, and other stressors following upregulation of HSP70 proteins (Clegg et al. 1998; Fabbri et al. 2008; Jackson et al. 2011).

Cumulative mortality during cold storage was substantially higher in June and August compared to September or October.
The time bivalves survive out of the water or "aerial survival" has often been measured to test their relative fitness, or as a sensitive indicator of environmental stress (Viarengo et al. 1995; de Zwaan and Eertman 1996). It is clear that using this indicator, oysters, in June and August, were significantly less able to withstand the additional stress of aerial exposure in cold storage than oysters in September or October. Oysters can generally survive for extended periods out of the water 
Table 2 Cumulative mortalities (\%) of oysters in study 2 after 7 days, 15 days, and 21 days of storage out of water at $4{ }^{\circ} \mathrm{C}$. Also shown are the results of chisquare analyses to test the effects of daily aerial exposure on cumulative mortalities at each sampling time. Different superscript letters represent statistical differences $(\mathrm{P}<0.05)$

\begin{tabular}{|c|c|c|c|c|c|c|c|c|c|}
\hline \multirow[t]{2}{*}{ Trials } & \multirow{2}{*}{$\begin{array}{l}\text { No. of } \\
\text { weeks } \\
\text { in the } \\
\text { field }\end{array}$} & \multirow{2}{*}{$\begin{array}{l}\text { No. of } \\
\text { hours of } \\
\text { daily air } \\
\text { exposure }\end{array}$} & \multirow[t]{2}{*}{$N$} & \multicolumn{3}{|c|}{ Cumulative mortality (\%) } & \multicolumn{3}{|c|}{$\chi^{2} P$ values } \\
\hline & & & & 7 days & 15 days & 21 days & 7 days & 15 days & 21 days \\
\hline \multirow[t]{6}{*}{ June 2009} & \multirow[t]{3}{*}{3} & 0 & 50 & $26^{\mathrm{A}}$ & $64^{\mathrm{AB}}$ & 88 & \multirow[t]{3}{*}{0.025} & \multirow[t]{3}{*}{0.044} & \multirow[t]{3}{*}{0.472} \\
\hline & & 10 & 50 & $28^{\mathrm{A}}$ & $76^{\mathrm{A}}$ & 90 & & & \\
\hline & & 18 & 50 & $8^{\mathrm{B}}$ & $52^{\mathrm{B}}$ & 82 & & & \\
\hline & \multirow[t]{3}{*}{6} & 0 & 50 & 20 & 70 & 88 & \multirow[t]{3}{*}{0.292} & \multirow[t]{3}{*}{0.134} & \multirow[t]{3}{*}{0.426} \\
\hline & & 10 & 50 & 24 & 54 & 80 & & & \\
\hline & & 18 & 50 & 12 & 52 & 88 & & & \\
\hline \multirow{6}{*}{$\begin{array}{r}\text { August } \\
2009\end{array}$} & \multirow[t]{3}{*}{3} & 0 & 46 & 17 & $61^{\mathrm{AB}}$ & 89 & \multirow[t]{3}{*}{0.160} & \multirow[t]{3}{*}{0.046} & \multirow[t]{3}{*}{0.313} \\
\hline & & 10 & 50 & 18 & $78^{\mathrm{A}}$ & 84 & & & \\
\hline & & 18 & 49 & 6 & $55^{\mathrm{B}}$ & 78 & & & \\
\hline & \multirow[t]{3}{*}{6} & 0 & 50 & 14 & 62 & 90 & \multirow[t]{3}{*}{0.882} & \multirow[t]{3}{*}{0.319} & \multirow[t]{3}{*}{0.505} \\
\hline & & 10 & 50 & 16 & 76 & 96 & & & \\
\hline & & 18 & 51 & 18 & 69 & 92 & & & \\
\hline
\end{tabular}

as long as the grow-out and storage temperatures are not excessively high. Like other bivalves, oysters with their shells closed rely on anaerobic metabolism and the production of energy by fermentation of glycogen and aspartate, following a reduction in metabolism, transcription, and protein synthesis (Larade and Storey 2009). The adenosine triphosphate (ATP) yield, however, is low compared with that available from the complete oxidation of carbohydrates by the tricarboxylic acid cycle under normoxic condition, and a large reserve of glycogen and amino acids is needed for maintenance under anaerobic metabolism (de Zwaan 1983). In summer, oysters, most likely, do not have the energy reserves to maintain their anaerobic metabolism during storage for an extended period, and the low ATP yield may prevent adductor muscles from keeping the valves shut, leading to the loss of shell cavity fluid, desiccation of the oysters, and death. Li et al. (2009) reported that the glycogen reserves are depleted and adenylate energy charge is lower in post-spawning oysters in summer, resulting in a suppressed metabolic activity. If the valves stay closed, anaerobic metabolism of oysters can also result in the buildup of carbon dioxide in tissues and eventually death (Michaelidis et al. 2005; Lombardi et al. 2013).

\section{Conclusion and future outlooks}

Exposing oysters to air periodically during grow-out in summer, prior to harvest, could not substantially reduce their cumulative mortality during cold storage. Summer conditions in NGoM, characterized by an extended period of high temperature and low food quality (Qian et al. 2003; Nababan et al. 2011), bring an associated reduction in energetic reserves that can have lethal effects when stressors are superimposed (Pernet et al. 2010; Sokolova et al. 2012). Increasing energy in reserve or limiting its depletion, in summer, may be a key to increasing oysters' shelf life. This might be done by manipulating the grow-out method or environment to limit the energy allocated to reproduction. Seed hardening, for example, is a practice adopted in Japan because it eliminated summer mass mortalities of Pacific oysters that were constantly immersed from rafts (Ventilla 1984; Mondol et al. 2016). It consists of exposing seed oysters to air daily during their first year of culture prior to immersing them constantly for a second year of growth. Smaller oysters whose growth have been stunted likely allocate less energy into gonad production and may have more reserves to tolerate summer stressors when continuously immersed during their second summer. Transfer of oysters to sites less suitable for gametogenesis (e.g., low salinity, low food availability) in the months prior to the reproductive season might also limit the risk of mortalities and possibly increase their shelf life as a phytoplankton-rich environment that promotes high oyster growth rate and reproductive effort (gonadic-to-somatic ratio exceeding 40\%) increases the risk of summer mortalities (Samain and McCombie 2008). Triploid Pacific oysters (Crassostrea gigas) due to their reduced reproductive effort have also been shown to suffer lower summer mortalities (Samain and McCombie 2008) and should be in better condition to survive cold storage out of the water in summer. Finally, oyster populations that may survive longer in cold storage could be selected. Families of greenshell mussels (Perna canaliculus), for example, were shown to vary significantly in aerial survival with families surviving longer out of water $\left(\mathrm{LD}_{50} \sim 17\right.$ days) upregulating anaerobic metabolism earlier than families surviving 


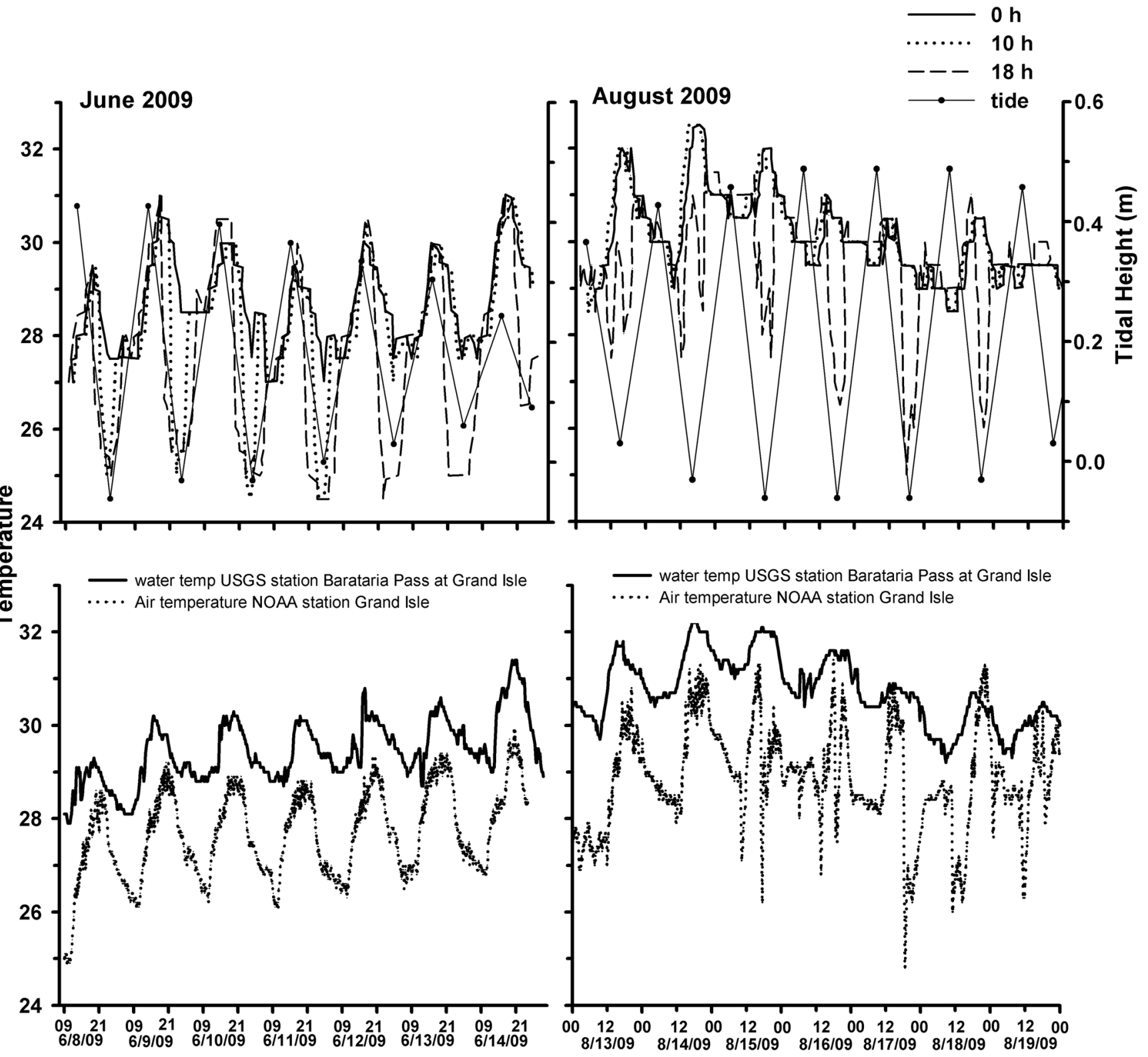

Fig. 3 Study 2. Top graphs show a 1-week extract of the temperature recorded in the June 2009 and August 2009 experiments in the ALS bags immersed $(0 \mathrm{~h})$ or exposed to air for $\sim 10 \mathrm{~h}$ or $\sim 18 \mathrm{~h}$ daily, as well as the tide height. Bottom graphs show the water temperature data obtained

from the USGS Barataria Pass station at Grand Isle (USGS recorder 073802516) and air temperature from the NOAA station at Grand Isle (GISL-1) for the same period. Hours and dates are indicated in the $\mathrm{X}$ axes

shorter time ( $\mathrm{LD}_{50} \sim 9$ days) (Powell et al. 2017). In eastern oysters, there is evidence of population and regional differences in the genetic and performance of eastern oysters (Barber et al. 1991; Varney et al. 2016; Leonhardt et al. 2017) and in adaptation to local estuarine salinity conditions (Burford et al. 2014; Leonhardt et al. 2017). It is therefore likely differences in aerial survival will be found and can be bred for to increase oyster shelf life during shipment in summer, therefore addressing a recurring problem for the oyster industry.

Acknowledgments The authors thank Yanli Li, Ton Sing Hong, and Yu Woen Chyi for their technical assistance in the laboratory and Dr. John Supan for providing oysters for the research.

Funding information This work was funded by the NOAA Gulf Oyster Industry Program through the Louisiana Sea Grant College Program grant no. NA16RG2249.

\section{Compliance with ethical standards}

Conflict of interest The authors declare that they have no competing interests. 


\section{References}

Andrews LS, Park DL, Chen Y-P (2000) Low temperature pasteurization to reduce the risk of Vibrio infections from raw shell-stock oysters. Food Addit Contam 19(7):787-791

Baker GL (2016) Food safety impacts from post-harvest processing procedures of molluscan shellfish. Foods 5:29

Barber BJ, Ford SE, Wargo RN (1991) Genetic variation and the timing of gonadal maturation and spawning of the eastern oyster Crassostrea virginica (Gmelin). Biol Bull 181:216-221

Brun NT, Bricelj VM, MacRae TH, Ross NW (2009) Acquisition of thermotolerance in bay scallops, Argopecten irradians irradians, via differential induction of heat shock proteins. J Exp Mar Biol Ecol 371:77-83

Burford MO, Scarpa J, Cook BJ, Hare MP (2014) Local adaptation of a marine invertebrate with a high dispersal potential: evidence from a reciprocal transplant experiment of the eastern oyster Crassostrea virginica. Mar Ecol Prog Ser 505:161-175

Cho SM, Jeong WG (2005) Spawning impact on lysosomal stability of the Pacific oyster, Crassostrea gigas. Aquaculture 244(1-4):383387

Clegg JS, Uhlinger KR, Jackson SA, Cherr GN, Rifkin E, Friedman CS (1998) Induced thermotolerance and the heat shock protein-70 family in the Pacific oyster Crassostrea gigas. Mol Mar Biol Biotechnol $7(1): 21-30$

Crawford C (2016) National review of Ostrea angasi aquaculture: historical culture, current methods and future priorities. University of Tasmania Institute for Marine and Antarctic Studies, Hobart, Tasmania. Report $44 \mathrm{pp}$

Cruz-Rodriguez LA, Chu FLE (2002) Heat-shock protein (HSP70) response in the eastern oyster, Crassostrea virginica, exposed to PAHs sorbed to suspended artificial clay particles and to suspended field contaminated sediments. Aquat Toxicol 60:157-168

De Zwaan A (1983) Carbohydrate catabolism in bivalves. In: Hochachka PW (ed) The Mollusca. Metabolic biochemistry and molecular biomechanics, vol. 1. Academic, pp 138-174

De Zwaan A, Eertman RHM (1996) Anoxic or aerial survival of bivalves and other euroxyc invertebrates as a useful response to environmental stress - a comprehensive review. Comp Biochem Physiol C 113(2):299-312

Encomio VG, Chu FLE (2007) Heat shock protein (HSP70) expression and thermal tolerance in sublethally heat-shocked eastern oysters Crassostrea virginica infected with the parasite Perkinsus marinus. Dis Aquat Org 76:251-260

Fabbri E, Valbonesi P, Franzellitti S (2008) HSP expression in bivalves. ISJ 5:135-161

Feder MA, Hofmann GE (1999) Heat-shock protein, molecular chaperones, and the stress response: evolutionary and ecological physiology. Annu Rev Physiol 61:243-282

Gillmor R (1978) Growth responses of European and American oysters (Ostrea edulis L. and Crassostrea virginica G.) to intertidal exposure. Proc Natl Shellfish Ass 68:79

Gillmor RB (1982) Assessment of intertidal growth and capacity adaptations in suspension-feeding bivalves. Mar Biol 68:277-286

Hargis WJ Jr, Haven DS (1999) Chesapeake oyster reefs, their importance, destruction and guidelines for restoring them. In: Luckenbach MW, Mann R, Wesson JA (eds) Oyster reef habitat restoration: a synopsis and synthesis of approaches. VIMS, Gloucester Point, pp 329-358

Hawkins AJS (1985) Relationships between the synthesis and breakdown of protein, dietary absorption and turnovers of nitrogen and carbon in the blue mussel, Mytilus edulis L. Oecologia 66:42-49

Hesselman DM, Motes ML, Lewis JP (1999) Effects of commercial heatshock process on Vibrio vulnificus in the American oyster,
Crassostrea virginica, harvest from the Gulf coast. J Food Prot 62(11):1266-1299

Huvet A, Normand J, Fleury E, Quillien V, Fabioux C, Boudry P (2010) Reproductive effort of Pacific oysters: a trait associated with susceptibility to summer mortality. Aquaculture 304(1-4):95-99

Jackson SA, Uhlinger KR, Clegg JS (2011) Duration of induced thermal tolerance and tissue-specific expression of $\mathrm{hsp} / \mathrm{hsc} 70$ in the eastern oyster, Crassostrea virginica and the Pacific oyster, Crassostrea gigas. Aquaculture 317:168-174

Kingsley DH (2014) High pressure processing of bivalve shellfish and HPP's use as a virus intervention. Foods 3:336-350

Kregel KC (2002) Invited review: heat shock proteins: modifying factors in physiological stress responses and acquired thermotolerance. $\mathrm{J}$ Appl Physiol 92:2177-2186

La Peyre JF, Casas S, Miles S (2014) Oyster responses to the Deepwater Horizon oil spill across coastal Louisiana: examining oyster health and hydrocarbon bioaccumulation. In: Alford B, Peterson MS, Green C (eds) Impacts of oil spill disasters on marine habitats and fisheries in North America. CRC, Boca Raton, pp 269-293

La Peyre JF, Casas SM, Supan JE (2018) Effects of controlled air exposure on the survival, growth, condition, pathogen loads and refrigerated shelf life of eastern oysters. Aquac Res 49:19-29

Larade K, Storey KB (2009) Living without oxygen: anoxia-responsive gene expression and regulation. Curr Genomics 10:76-85

Leonhardt JM, Casas S, Supan JE, La Peyre JF (2017) Stock assessment for eastern oyster seed production and field grow-out in Louisiana. Aquaculture 466:9-19

Li Y, Qin JG, Abbott CA, Li X, Benkendorff K (2007) Synergistic impacts of heat shock and spawning on the physiology and immune health of Crassostrea gigas: an explanation for summer mortality in Pacific oysters. Am J Physiol Reg I 293:R2353-R2362

Li Y, Qin JG, Li X, Benkendorff K (2009) Spawning-dependent stress responses in pacific oysters Crassostrea gigas: a simulated bacterial challenge in oysters. Aquaculture 293(3-4):164-171

Lindquist S, Craig EA (1988) The heat-shock proteins. Annu Rev Genet 22:631-677

Littlewood DTJ, Wargo RN, Kraeuter JN, Watson RH (1992) The influence of intertidal height on growth, mortality and Haplosporidium nelsoni infection in MSX mortality resistant oysters, Crassostrea virginica (Gmelin, 1791). J Shellfish Res 11:59-64

Lombardi SA, Harlan NP, Paynter KT (2013) Survival, acid-base balance, and gaping responses of the Asian oyster Crassostrea ariakensis and the eastern oyster Crassostrea virginica during clamped emersion and hypoxic immersion. J Shellfish Res 32: 409-415

Michaelidis B, Haas D, Grieshaber MK (2005) Extracellular and intracellular acid-base status with regard to the energy metabolism in the oyster Crassostrea gigas during exposure to air. Physiol Biochem Zool 78:373-383

Monari M, Foschi J, Rosmini R, Marin MG, Serrazanetti GP (2011) Heat shock protein 70 response to physical and chemical stress in Chamelea gallina. J Exp Mar Biol Ecol 397:71-78

Mondol MR, Kim CW, Kang CK, Park SR, Noseworthy RG, Choi KS (2016) Growth and reproduction of early grow-out hardened juvenile Pacific oysters, Crassostrea gigas in Gamakman Bay, off the south coast of Korea. Aquaculture 463:224-233

Nababan B, Muller-Karger FE, Hu C, Biggs DC (2011) Chlorophyll variability in the northeastern Gulf of Mexico. Int J Remote Sens 32(23):8373-8391

Pernet F, Barret J, Marty C, Moal J, Le Gall P, Boudry P (2010) Environmental anomalies, energetic reserves and fatty acid modifications in oysters coincide with an exceptional mortality event. Mar Ecol Prog Ser 401:129-146

Powell JA, Ragg NLC, Dunphy BJ (2017) Phenotypic biomarkers in selectively-bred families of the Greenshell mussel (Perna canaliculus): anaerobic enzyme and shell gape behaviour as 
biomarkers of prolonged emersion tolerance. Aquaculture 479:601608

Qian Y, Jochens AE, Kennicutt MC II, Biggs DC (2003) Spatial and temporal variability of phytoplankton biomass and community structure over the continental margin of the Northeast Gulf of Mexico based on pigment analyses. Cont Shelf Res 23:1-17

Roberts DA, Hofmann GE, Somero GN (1997) Heat-shock protein expression in Mytilus californianus: acclimatization (seasonal and tidal-height comparisons) and acclimation effects. Biol Bull 192: 309-320

Ronholm J, Lau F, Banerjee SK (2016) Emerging seafood preservation techniques to extend freshness and minimize Vibrio contamination. Front Microbiol 7:350

Samain JF, McCombie H (2008) Summer mortality of Pacific oyster Crassostrea gigas: the Morest project. Ifremer/Quae Editions, Versailles

Sanders BM (1993) Stress proteins in aquatic organisms: an environmental perspective. Crit Rev Toxicol 23(1):49-75

Sokolova IM, Frederich M, Bagwe R, Lannig G, Sukhotin AA (2012) Energy homeostasis as an integrative tool for assessing limits of environmental stress tolerance in aquatic invertebrates. Mar Environ Res 79:1-15

Supan JE, Wilson CA (2001) Analyses of gonadal cycling by oyster broodstock, Crassostrea virginica (Gmelin), in Louisiana. J Shellfish Res 20:215-220
Ueda N, Ford C, Rikard S, Wallace R, Boettcher A (2009) Heat shock protein 70 expression in juvenile eastern oysters, Crassostrea virginica (Gmelin, 1791), exposed to anoxic conditions. J Shellfish Res 28(4):849-854

Varney RL, Sackett RE, Wilbur AE (2016) Analysis of spatiotemporal genetic variability in eastern oyster Crassostrea virginica (Gmelin, 1791) Mtdna 16S sequences among North Carolina populations. J Shellfish Res 35(2):329-343

Ventilla RF (1984) Recent developments in the Japanese oyster culture industry. Adv Mar Biol 21:1-57

Viarengo A, Canesi L, Pertica M, Mancinelli G, Accomando R, Smaal AC, Orunesu M (1995) Stress on stress response: a simple monitoring tool in the assessment of a general stress syndrome in mussels. Mar Environ Res 39(1-4):245-248

Wang J (2015) Quality evaluation of live eastern oyster (Crassostrea virginica) based on textural profiling analysis, free amino acids analysis, and consumer sensory evaluation. Master thesis, $76 \mathrm{pp}$. Auburn University

Zhang J, Walton WC, Wang Y (2017) Quantitative quality evaluation of eastern oyster (Crassostrea virginica) cultured by two different methods. Aquac Res 48:2934-2944

Publisher's note Springer Nature remains neutral with regard to jurisdictional claims in published maps and institutional affiliations. 